\title{
High Altitude Hospitality
}

\author{
Basant Prasad Joshi ${ }^{\star}$
}

\begin{abstract}
Most of the books and journals of hospitality and tourism, generally talk about history, trends and components of hospitality as a newly emerging discipline but there are a few books could only make significant contribution on the prospects, challenges and opportunities for hospitality especially in high altitudes where the challenges are ample. People would basically be interested to travel to altitudes to crave the places of adventures specially trekking, hiking, mountaineering, rock climbing, snow skiing, etc. Providing hospitality in high altitudes is a very perplexing task where there is always a scarcity of man, material and management. Hochschild (2003) in his book The Managed Heart explains about the human factors that are important in providing hospitality services. The importance of feelings and its belongings on the offered services to the client and guests has a direct bearing on the overall experience and this experience is much important in high altitudes where the sentimental values are more important than the physical elements of a good service.
\end{abstract}

Keywords: Altitude sickness, Emotional labor, Teashops, Alps

\section{Introduction and overview}

Hospitality basically refers to the relationship between host and guest has a history connoted with very early Greek times when people used to gather in a common place for festivals, religious purpose or rituals. (Kunwar 2017, p.56) stated, "Most of the people in hospitality sectors refer to hospitality as the friendly and welcoming behavior towards the guests. Frequently, such a friendly and welcoming behavior may include sharing food, drinks and accommodation with the realm of shared happiness resulting in the establishment and maintenance of lasting relationships. In fact, the host-guest relationship serves as a power and control measure" In these times, the hospitality services were for social causes only. It was about this time that the concept of thermal bath came into existence for healing and relaxation. These thermal baths now a day have turned into the modern day Spas. According to the early history of Hospitality about $40 \mathrm{BC}$, the Romans who provided accommodation to the travellers

* Basanta P. Joshi is Director/Head of School, School of Hotel Management/Asian Institute of Management (AITM),, Khumaltar, Lalitpur Email: basantpjoshi@gmail.com 
in Government premises travelled from one place to another for trade purpose and when they travelled seek for pleasure, comfort and entertainment leading to the development of this industry at large.

Researcher in this study finds that the most of the books and journals of hospitality and tourism, generally talk about the history, trends and components of hospitality as a newly emerging discipline but there are a few books could only make significant contribution on the prospects, challenges and opportunities for hospitality specially in High altitudes where the challenges are ample. People basically travel to Altitudes to crave the places of adventures specially trekking, hiking, mountaineering, rock climbing, snow skiing, etc.Providing hospitality in High altitudes is a challenging task where there is always a scarcity of man, material and management. We use the word management to show up its direct proportionality with the man as a primary element of providing Hospitality. We have been living in the modern age where people travel for pleasure and find the most amazing yet very exhilarating destinations to have a very vacationing experience. Nepal as being a world destination for altitude climbing has a history connoted with Mt. Everest, the highest peak of the world. The fundamentals of this study lies on finding as to how the lives are surviving in these destinations? What are the challenges associated to High altitudes to provide real time hospitality to visitors? What developments are going on in these destinations? What are the Basic Hospitality tools used for bringing the hospitality to a level? To have the answer to these all the questions, Researcher used a very pragmatic survey in the different High altitude destinations in Nepal.

For this kind of study, research based conduct is important. Researcher conducted the study based on unstructured questionnaire in the different High altitude tourist destinations of Nepal like Everest Region, Langtang Valley, Helambu and Gosai Kunda, also the researcher took feedback from the trekkers in different regions especially from the Upper Mustang area. The trekkers in Upper Mustang area from Tukuche to Muktinath to Gnami to Lo-manthang to Sangboche, Kagbeni to Lete to Ghasha to Beni to Pokhara were asked about their experience in the journey. About 15 cooks of this region and about 15 Porters and more than 50 travellers of the region were taken interview during the research related to food, drink, hospitality, prospects and problems in high altitude areas and the hospitality offerings.

\section{Historical Overview of Hospitality}

Medieval Period considered in between 5th to 15 th Century was the period of Western Roman Empires and merged in to the age of modern discovery has provided a lot for the growth of Hospitality Industry. This is where the English travel and do excursion in their own privately owned residences. This further gave rise to the existence of Caravanserais that provided some resting places of the caravans, the 
group of people travelled together for some trade purpose. These places then turned into the first places to offer refuge to travellers.

Persians in this period acted smart to establish further inns and post houses in the routes of caravans which then used to offer accommodation to the soldiers and couriers. In a book by Marco Polo, he estimated to have 10,000 such post houses in a distance of 25 KM. Marco Polo's book “The Travels of Marco Polo" gave significant contribution to what should be offered to a modern day traveller. In the year 1282, in Florence, Italy, an innkeeper formed an association with turning hospitality to a business with its own right, took government permission to sell wine and was spread into the rest of the world as hospitality industry elsewhere. (https://soegjobs.com)

In 14th Century which is regarded as the most important period to start the formal opening of the Hotel Industry with the opening of Hotel Koshu Nishiyama in Japan. Hotel De Henry or Hotel de Salm in around 1788 in 16th Century in France was the next hotel of third era to give rise to the formal opening of Hotel industry in the world, names of this hotel changes over the years. These Hotels have created trends to have more openings in New York, England and other Southern colonies. After the French revolution for far-reaching social and political upheaval in France that lasted from 1789 until 1799, there were quite noteworthy developments made in the Culinary Arts and Hospitality Industry by Chefs like Escoffier and M. Boulanger who took the culinary standards to other heights.

In the 19th Century, the development has spread in a great way opening Savoy Hotel in London, Delmonico in New York followed by tourist standard hotels in other part of the world creating better standards in Hospitality Industry. Two consecutive world wars in 19th Century has disturbed the growth of Hotel/hospitality Industry at large turing the entire tourism industry to be called dark tourism or 'Thanatourism' In the industrial revolution starting 1970's, the construction of new hotels in Europe, England and America paving ways to open new hotels in Far east.

Modern Hospitality after 20th Century has modern architects, engineers, developers, and managers further has the hospitality academies producing competent hospitality professionals has been regarded as the most important industry of the world. Today the Hotel industry has developed a lot giving choices to the travellers to make their stay a most memorable one. We have many chain Hotels namely: Ritz Carlton, Sheraton, Hilton, Radisson, Hyatt, Marriott, Starwood, etc.

\section{Etymology of Hospitality}

Hospitality refers to a benevolence relationship between the host and guest where as the host receives the guest with goodwill, honor and diligence. Louis, chevalier de Jaucourt describes hospitality in the Encyclopédie as the virtue of a great soul that cares for the whole universe through the ties of humanity. 
Derives from the Latin hospes, meaning "host", "guest", or "stranger". Hospes is formed from hostis, which means "stranger" or "enemy" (the latter being where terms like "hostile" derive). By metonymy the Latin word 'Hospital' means a guest-chamber, guest's lodging, and an inn. Hospes is thus the root for the English words host (where the $\mathrm{p}$ was dropped for convenience of pronunciation), hospitality, hospice, hostel and hotel.

Western world today celebrate hospitality as etiquette and entertainment and rarely a matter of protection and survival. However, it still shows the respect for guests, providing them with their needs and wants by treating those equals. Cultures and subcultures vary in the extent to which one is expected to show hospitality to strangers, as opposed to personal friends or members several recent definitions of hospitality activities are interesting because they confirm the current preoccupation to commercial provision.

Joint Hospitality Industry Congress (JHIC, 1996) and the Higher Education Funding Council- England (1998) defined hospitality in industrial/commercial term as a cluster of services provided by a variety of organizations in different sectors of the industry. Since this definition is broadly related to the supply of goods and services hence are economic in nature. The major focus of this definition is the service nature of this industry and hence is totally dedicated to commercial provisions of hospitality. That said, these economic definitions are essentially limited and flawed by their preoccupation with the here and now.

A wider understanding of hospitality suggests firstly that hospitality is essentially a relationship based on host and guest. To be effective, hospitality requires the guest to feel that the host is being hospitable through feelings and generosity, a desire to please, and a genuine regard for the guest as an individual. Consequently, calculative hosting where the guest senses a hidden motive can be counterproductive. A second point flowing from this wider understanding is that the current commercial provision of hospitality provides but one avenue for the exploration of hospitality. The social domain assists in setting the study of hospitality and the component elements in a wider social context. The value placed on being hospitable, caring for strangers, assisting the poor and providing hospitality to those in need, within a society's value system, is an additional and fruitful line of enquiry. Similarly, the relationship between guest and host still takes place in private settings of one's in group. (Lashley \& Morrison, 2000)

In India and Nepal hospitality is based on the code of Atithi Devo Bhava. The guest is equivalent to God is taken from an ancient Hindu scripture which became part of the "code of conduct" for Hindu society. This principle is shown in a number of stories where a guest is revealed to be a god who rewards the provider 
of hospitality. From this stems the Indian practice of sociability towards guests at home and in all social situations. Nepal and India follow almost the similar pattern of hospitality but differs in many ways based on the regional choices and cultural understandings.

Mosaic at San Vitale, Ravenna, Abraham and the angels, pre-547 ,Judaism praises hospitality to strangers and guests based largely on the examples of Abraham and lot in the Book of Genesis (Genesis 18:1-8 and 19:1-8). In Hebrew, the practice is called hachnasat orchim, or "welcoming guests". Besides other expectations, hosts are expected to provide nourishment, comfort, and entertainment to their guests, and at the end of the visit, hosts customarily escort their guests out of their home, wishing them a safe journey.

One of the main principles of Pashtunwali is Melmastia. This is the display of hospitality and profound respect to all visitors (regardless of race, religion, national affiliation or economic status) without any hope of remuneration or favor. Pashtuns will go to great lengths to show their hospitality.

Celtic societies also valued the concept of hospitality, especially in terms of protection. A host who granted a person's request for refuge was expected not only to provide food and shelter to his/her guest, but to make sure they did not come to harm while under their care.

Even in historical myths the term hospitality has been generously offered by a mankind to the god and among themselves. "Duryodhan ki Mewa Tyagi, Sag Bidur Ghar Khai, Sabse Onchi Prem Sagai." (Shreemad Bhawat Geeta, p. 618). The hospitality provided to lord Krishna by Bidur is an example where lord Krishna eats simple boiled green vegetables as being served with heart in Bidur's house but he denied eating dry nuts and savories in the house of Duryodhana (villain of Mahabharata). This shows that the hospitality for a showmanship has very less receiving as long as the hospitality for hospitality from the heart does exist.

Jagatguru Shree Kripaluji Maharaj the fifth original Jagatguru (World Teacher and Moderator of all the religions) in his book Prem Ras Siddhanta, the philosophy of divine love (Kripaluji Maharaj, 1955) stated, "Service and hospitality should be as per the wish of his master not the wish of his servant or the service provider. Any service or hospitality given as per the wish of his master or service beholder is a true service or hospitality"

\section{High Altitude Hospitality an Emerging Castigation}

High altitude is considered as the level more than 3000 feet above sea level although the boiling point of water at 2000 feet is $208^{\circ} \mathrm{F}$ instead of $212^{\circ} \mathrm{F}$. In the west world, Alaska, Arizona, Colorado, California, South Dakota, Texas, Utah, Washington 
and Wyoming are situated at high altitudes but not in that high as compared to the mountains of Nepal.

With the increasing rate of the travelers who crave to visit many places of adventures specially related to this subject for e.g. trekking, hiking, mountaineering, rock climbing, snow skiing, etc, the concept of the High altitude Hospitality starts putting its feet in. When people travel in high altitudes in search of peace, adventure and the natural belongingness, the high altitude hospitality discipline should flinch in serving their needs in those places. This has become an emerging castigation because of its nature and fame. Traveling in high altitudes is an adventure, fun, flair and fascination. When this area of tourism exists the hospitality follows. Hospitality at high altitude is really challenging as there is always a scarcity of man, material and resources. This study focuses on the Nepalese high altitude hospitality with its connotation to the rest of the world.

\section{Tourism and Hospitality in European Alps}

Alps are one of the most exciting destinations in the world, are adventures and risky to life if not planned well. Oberstdorf in Bavaria, Saalbach in Austria, Davos in Switzerland, Chamonix in France, and Cortina d'Ampezzo in Italy are annually visited by more than 120 million visitors. Tourism in these destinations is an integral to the Alpine economy with much of it coming from winter sports, although summer visitors are also an important component.

The term Alpine states or Alpine countries refers to the territory of eight countries associated with the Alpine region, as defined by the Alpine Convention of 1991: Austria (28.7\% of the total area), Italy (27.2\%), and France (21.4\%), which represents more than $77 \%$ of the Alpine territory and more than three quarters of the Alpine population. From a strictly national point of view, and with the exception of microstates Liechtenstein and Monaco, the Alps are dominant in only two countries: Austria (65.5\% of its territory) and Switzerland (65\%).

It is said that the people started visiting the alps in around 19thcentury in search of peace and to get connected with the nature, scenic beauty and then started staying for Spa, a kind of natural spring water bathing for medicinal purpose specially in high mountains where the water carries some essence and oils of the high mountain herbs and medicinal botanicals making water to act as medicine. The origin and evolution of cog-railways in 20th century helped the tourists to bring them even more high mountains, well above the touch line of the snow capped mountains. During 19th century the concept of winter sports were introduced and in 1882 the first figure skating championship was held in St. Moritz, Switzerland followed by a downhill skiing in 20th century with the installation of the first ski-lift in Grindelwald around 1908. 


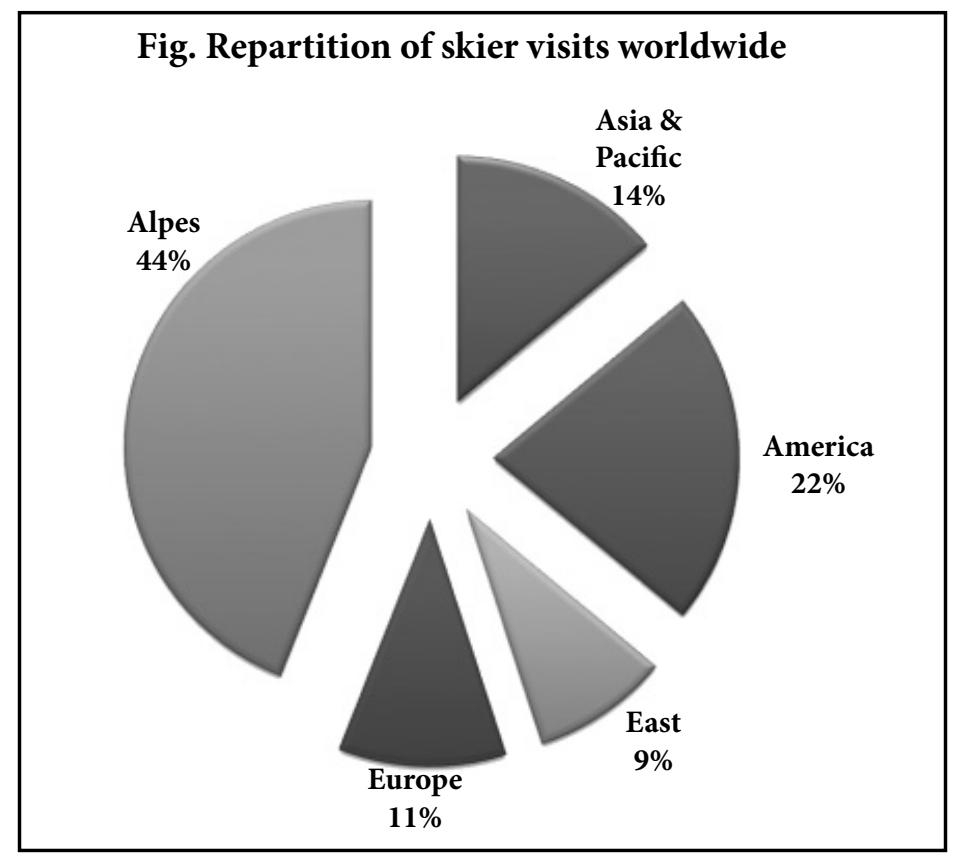

Fig. 1. Repartition of skier visits worldwide

Winter Olympic Games also brought the people in high altitude venues. For example in the first half of 20th century, Olympic winter games were held three times consequently in 1924 in Chamonix, France, in 1928 in St. Moritz, Switzerland and in 1936 in Garmisch, Partenkirche, After world war II, the winter games have beren held in in St. Moritz (1948), Cortina d'Ampezzo (1956), Innsbruck, Austria (1964 and 1976), Grenoble, France, (1968), Albertville, France, (1992), and Torino (2006).

Alpine tourism has the history associated with the introduction of ski-lifts in Switzerland and in Austria for winter visitors and also in the mid of 20th century the popularity of downhill skiing in the villages of France. Austria and Switzerland were famous for the winter sports till 1970's and after then winter tourism has become famous in France, Italy and Tyrol.

\section{Nepalese High altitude Teashops andHospitality}

Nepal is a mountainous country and famous in the world for having eight peaks which are above $8000 \mathrm{~m}$ height including Mount Everest, the highest peak of the world.Nepal is famous for its adventurous yet very nature connecting destinations. A concept of village tourism/homestay tourism has been into practice in recent days and is gaining popularity after a Visit Nepal year 2011 movement by Nepal tourism 
board to attract more visitors in Nepal. People from round the world come to Nepal to travel to the sky touching mountains, experience adventure and more over to get connected with the wildly available flora and fauna. Nepal is rich in mountain herbs, spring waterand organicfood (medicinal in nature). Data shows that it has about 848 varieties of birds, $8 \%$ of total birds of the world, total $4 \%$ mammals, 11 out of 15 varieties of butterflies, 600 varieties of local plants and more interestingly as explained above the eight out of eleven eight thousand meter high mountains are in Nepal including Mount Everest which is the largest among all and named after British Engineer Mr. George Everest.

Nepal's Alps are interesting and people living in these areas are daring and hospitable. Nepal is not only famous for its land escape, Alps, Mountains and Himalayas, but also for the people and their hearts. Nepalese show their hospitality from the core of their hearts as they are spiritual in nature and have a strong belief in the guest whom they treat equivalent to the god.

Approximately $83 \%$ of land mass from a total of the $1,41,181$ sq. km (Nepal CBS, 2006) areaof Nepal is covered with mountain landscapes including Himalayas, however, attributedwith pristine nature and culture. Out of more than 3,500 km. vast extensions of thehighest Himalayas termed as Hindu Kush - Himalaya ranging from Afghanistan in thenorth-west to Myanmar in the south-east, Nepal's Himalaya has covered approximately 800 sq.km beginning from Byasrishi Himal in Darchula in the west to Kanchejunga in the east(Upadhayaya \& Upreti, 2008).

In the midst of around 1792 mountain peaks existed in Nepal, 1310 peaks are above6000 meter and only 326 peaks have been opened for climbing (TAAN, 2008).The four ranges of mountains covering Sivalik, Mahabharat, Mid Hill and highHimalayas with valleys in between are inhabited by a range of different communities. The communities are a mixture of various castes, ethnic people, and indigenous groupsfrom Tibeto Mongoloid and Indo Aryans races with their age-old rich cultures andtraditions. Alps are famous in Nepal for having lots of mountainous herbs and medicines; Api Mountain in Darchula is famous for having a new botanical as well as biological herb called Yarchagumba. This has been regarded as the most expensive bio-botanical herb of the world. This is regarded as half the plant and half the snow insect.

Mountain regions are generally characterized by irregular \& steep relief ofland/ surface, deep gorges, low temperature, fragile ecology, and poorsoil,limited choice of crops, remote isolated villages, low oxygen pressure, and low humidityof air. (Upadhayaya, 2006). Mt. Everest 8848m, Kanchenjunga 8586m, Lhoste 8501m, Makalu, $8463 \mathrm{~m}$, Cho Oyu, 8201, Dhaulagiri, 8167, Manaslu $8156 \mathrm{~m}$ are the common important mountains which are elevated from the year 1953 till 1960 by different mountaineers. 
Trekking in Nepal has a history connoted with the locally known teahouses known as "Bhatti's" these small teahouse are taken as the starting points, connecting points and resting and ending points of the entire journey and are key to the entire experience. Sometimes, these teahouses literally serving wood fired locally made tea with some snacks have the lodging facilities with few beds on first or second floor with a minimum of the facilities for the guests for e.g. a wooden or metallic bed with jute netted base, a good mattress, bed sheets, good quilt or blanket and Pillow. Goodterrazzo flooring and a simple corrugated sheet shades enough for spending one or two nights. Attached bathrooms with hot and cold water are also provided in majority of the tea houses. The term tea houses can also be understood as guest houses with a minimum of accommodation and food facility.

Nepal in the current years has been suffering from load shedding which sometimes is more than 18 hours a day has badly affected the operation of these guest houses and is difficult to maintain many guest related facilities for e.g. hot water, mobile charging, water boiling, etc. however for the daily cooking purposes wood fire is the mean which is readily available in all the guest houses. In the winter season, the basic mean of heating is also the wood fire chamber which is locally known as chimney spreads from the restaurant to all the rooms till the roof for ventilation. The heat from the hearth goes via a tunnel to all the rooms and is escaped to the roof; this on the way makes the room warm. The provision of Hospitality in mountainous routes of Nepal is exciting yet very limited but the visitors have a unique experience of these routes while interacting with the people and the hospitality they offer from the core of the heart. The condition of the hospitality providing institutions are not improved yet for e.g. the animals are slaughtered at homes or in the hotels in locally acceptable conditions but not in slaughter houses because of not having the provision of it. Some of the hotels are seen with the walls of rooms coated with locally available colorful mud as paint but is risky as if touched comes in hands and sometimes can make the clothes dirty. Storing food is a complication because of non-availability of the commercial store rooms and also because of the heavy load shedding. This is how it is obvious to get the fresh food in every hotel. Availability of spring water (very natural herbal water) is the main attraction of the region as each hotel provides the same water for drinking after boiling. Travelers can drink the water straight from the tap because of the water coming from the direct source instead of coming from the preserved tanks. Since most of themountainous areas are difficult to transport, people rely on the house made organic fertilizer for their farms hence making each farm product an organic one. Visitors have a chance to get the fresh products which are organic in nature. 


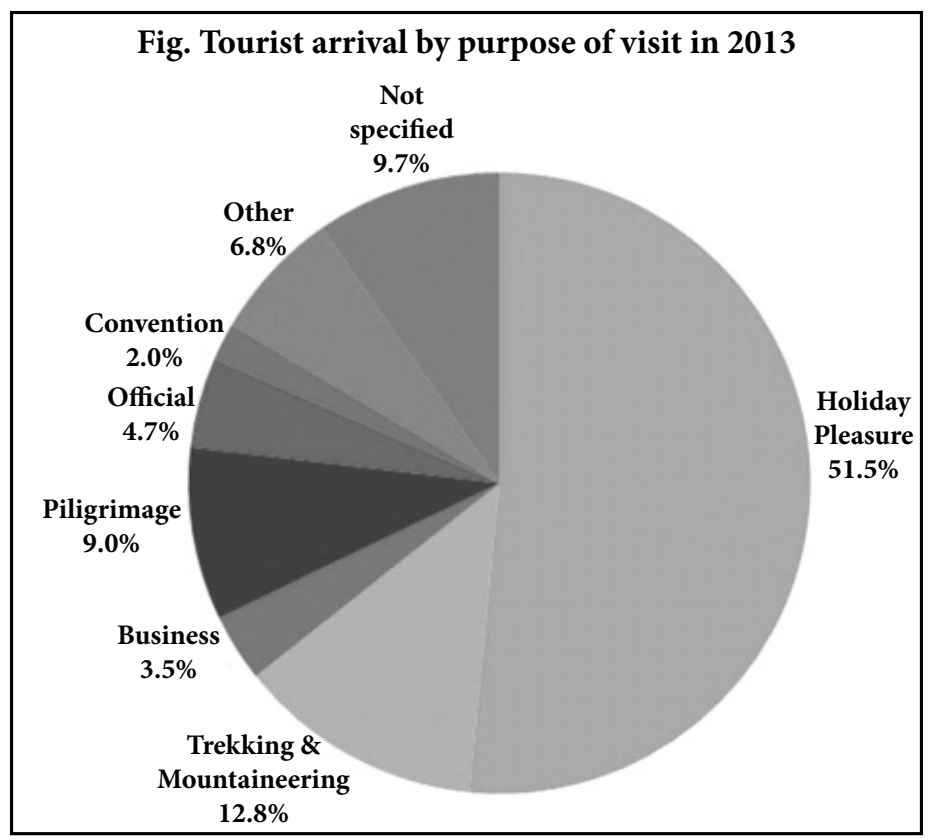

Fig. 2, Tourist arrival in Nepal by purpose of visit in 2013

Elevating from the green suburbs in the beginning to the wide dessert valleys in the middle with snowcapped trekking ways to the sky touching bright and fresh Himalaya makes it a great journey. On the way it is obvious to see the local lifestyle in some of the routes for e.g. towards Annapurna circuit, the local life style makes it a show case of what Nepal has to offer to the foreigners with survivalability and happiness living in the most difficult conditions. The system of water supply in homes and hotels, Mills, Wood fire, Local architecture, local schools, local festivals, museum, and entertainment and also the wild life are some of the important and exciting endeavor for travelers.

Sunrise is the main attraction of Pun Hill in Annpurna region situated in $3100 \mathrm{M}$ height. Early morning hundreds of travelers visit to the top of the hill surrounded by the range of great white Himalayas waiting to give a reflection of golden rays of an innate sun in the morning. The conversion of the color of the entire mountain range in a few minutes of time is what travelers want to see after many days journey. The closeness of the nature with peace and tranquility are the products in offer.

\section{Challenges in High altitudes}

High altitude sickness

A high altitude climbing is an extreme difficulty when we get to the top of the peaks. Every time we take a breath; we are only taking $60 \%$ of the oxygen molecules. 
That is an extreme stress because our body needs a continuous supply ofoxygen. We cannot store up oxygen like we do for our calories required. Instead we have to have a continuous supply going to our mitochondria all the times. So this is a problem for the people at sea level who travel to the peaks, where the amount of oxygen is very less which can even lead to medical problems including altitude sickness.

\section{Constipation}

Constipation is actually a quite common complaint at altitudes, where decreased oxygen slows down the function of the intestines and excessive fluid losses rob water from the colon (NAMOHAE, p. 3) The opposite can also occur due to food preparation with less-than-adequate hygiene; diarrhea is quite common among climbers in Africa

Hypoxia

Human body has a long history and is genetically able to cope up with the extreme conditions of either decrease in oxygen situations or infections in lungs causing hypoxic conditions or in anemic situations where we do not carry same amount of oxygen as we carry in the sea level. We also caught up with the diseases like sleep apnea causing the people to stop berating for some times causing hypoxia.

The archeological evidences show that the people started living in high altitudes for more than 11000 years ago by following the migration of the animals. It is very difficult to predict that why people actually started living in high altitudes in the earlier times and settled permanently. Some investigations in Andean Plateau shows that the people started living in high altitudes rather than visiting occasionally. It is also found that in Tibet someone visited about 35000 years ago but not to stay permanently.

The studies from a French doctor named Vault in 1980 showed that the blood cells of the people living in Andean highlands are more than in a normal sea level people he also noticed high level of hemoglobin, wide chests, wide lungs and a very special breathing rhythm. The question comes if the same pattern is found everywhere in the world? (Cynthia Beall, 2011)

This study shows that the people living in these high altitudes carry very special characteristics in one way or another. This is the reason why it is very important to understand the diversity of the human body to adapt the situations. High altitudehospitality is based on the facts drawn from studies carried in past and present. No hospitality can be perfect without understanding the comfortability of the people traveling or living in these destinations.

\section{High altitude Food and Beverages}

Food and beverages being an important part of high altitude travelling, it is important to have a good balance of nutrients with a small consumption as the amount of oxygen is less and the food items should be easily converted into the required energy. 
Oxygen is important as more than $90 \%$ of the conversion of the energy of food is not possible without oxygen. As food and beverages being the most important element of hospitality, it is important to know the different parameters in which the food and beverages can be offered to the travellers so as to make their experience a better one.

It is very important that the people should understand the universal cooking techniques will not be applicable in high altitudes. Air pressure decreases about $1 / 2$ pound per 1000 feet height. Following table shows the level of pressure and height.

\section{Level}

Sea Level

$5000 \mathrm{ft}$.

$10000 \mathrm{ft}$.

\section{Air Pressure per square inch}

At higher elevations, because of less pressure of air, the liquids from the food evaporate faster as the liquids evaporate in lower temperature and this way, the cakes and other bakery products expand faster. This may be understood two ways.

1. The food products can be cooked faster for those which require less time and temperature

2. Food items might be raw and take longer time to cook because of the molecular formation and complexity of the food items.

Following are the different characteristics and activities in food and beverages in high altitudes

- The boiling point of the water decreases by $1^{\circ} \mathrm{F}$ by every $500 \mathrm{ft}$. elevation

- Food items to be prepared by boiling take longer time than usual

- High latitude areas are lower in humidity and it needs the food to be covered during cooking

- Pressure cookers work better which retain the moisture and hold the evaporation to an extent

- Turning up heat doesn't cook the food faster as it doesn't increase the boiling point of water.

- Recipes used to cook the food and bakery items do not work exactly at high elevations. These way small adjustments are required in boiling potatoes, eggs or making roast items and bakery products.

Researchers from Colorado State University, Department of Food Science and Human Nutrition found that food preparation in high altitudes basically affected in two different ways 
1. Water and other liquids in high altitudes evaporate faster and can be boiled in lower temperature

2. Gases in the breads and cakes basically expand more faster

Even at sea level, meat and poultry (as well as low-acid vegetables and fish) must be processed using a steam pressure canner. If using a dial gauge at high altitudes, the pressure in the canner must be increased by 1 pound of pressure for each 200 feet above sea level. If using a weighted gauge, the 15 pound weight must be used at all altitudes above 1,000 feet. It is not required to add additional processing time if the pressure of the canner is adequately adjusted. (Kendall, 2013)

\begin{tabular}{|c|c|}
\hline \multicolumn{2}{|c|}{ Pressure Required to Reach $\mathbf{2 4 0}^{\circ} \mathbf{F}$} \\
\hline ALTITUDE & PRESSURE REQUIRED \\
\hline Sea Level to2,00 feet & 11 Pounds \\
\hline 2,001 to4,000 feet & 12 Pounds \\
\hline 4,001 to6,000 feet & 13 Pounds \\
\hline 6,001 to8,000 feet & 14 Pounds \\
\hline 8,001 to10,000 feet & 15 Pounds \\
\hline
\end{tabular}

Table.1, Pressure required to reach $240^{\circ} \mathrm{F}$

To avoid the risk of botulism bacteria, all canned foods should be canned as per the recommended guidelines. In every 1000 feet additional elevation, need to boil for an additional 1 minute to prevent and kill clostridium botulism bacteria widely found in foods. For example, at 3,000 feet, we need to boil food for 12 minutes. Due to high density, spinach and corn are boiled for about 20 minutes in all altitudes.

Many cooking methods can be used to cook eggs safely at high altitudes including poaching, hard cooking, scrambling, frying and baking. In general, do not increase the heat, just increase the cooking time. Eggs must be cooked thoroughly until yolks are firm. Scrambled eggs should not be runny. Casseroles and other dishes containing eggs should be cooked to $160^{\circ} \mathrm{F}$. Use a food thermometer to be sure.

At high altitudes, extra-large eggs give added moisture and structure to baked goods and desserts. Smaller eggs will result in batter that is less stable and more likely to fall during baking. Also, increasing the amount of egg strengthens the cell structure and may prevent the too-rich cake from falling.

To determine what might work best in high latitudes, it is advisable to test out a variety of foods at elevations above 10,000 feet and scrap what doesn't appeal there, as it probably won't get any more palatable higher up. It is always advisable to take the tastiest foods we can find, and plenty of different options, as it is likely only get increasingly finicky higher up. Try to ward off monotony; it can't be imagined 
anything worse than having the same food 4-5 days in a row if we didn't like it the first time we tried it.

Cannedfoods which does not require toomuch freezing and easy to open and does not contain much carbondioxide are advisable in high altitudes. Following are some of the most common food items for trekkers in alpine region.

Breakfasts: granola or energy bars, Pop tarts, oatmeal, bagels, hot sweet rice, couscous, grapenuts, hot cocoa, tea and cider

Lunches: crackers (wheat thins, Ritz, Cheezits), cookies, bagels or rolls, jerky, sausages, cheese sticks, nuts, candy bars, dried fruits, flavored juice drink mixes, fruit leather, fig bars, hard candy, trail mix

Dinners: cocoa, cider, soups, hot jello, and teas as the first course; freeze dried meals with rice, noodles, vegetables; instant rice, stuffing, or mashed potatoes; pudding or mousse for desserts

\section{Findings and recommendations (Study and observations of Nepalese High altitudes)}

In the Nepalese trekking routes, normal Nepali food is easily available. However, there is a fixed menu for touriststo have continental food which is not available to Nepalese local tourists. Due the road conditions and accessibility, Food cost is high and this is creels the affordability for the local tourists. Some destinations like Annapurna Circuit have the community benchmarks for the menus. There are the same rates and items in the menu however are lacking the consistency, quality and quantity of food served. It is all different in all the outlets or eateries. Menu has the combination of western as well as Asian food choices for example: Spaghetti Neapolitan, Roasted Chicken, Fried Fish, Omelets, Fried Eggs, Pizza, Chowmein, Fried Rice, Porridge, Fresh Cut Fruits, etc. are very commonly available items. Because of load shedding in these areas Pizza and other bakery items requiring electricity for cooking are sometimes not available. Road conditions and problems in transportation of raw materials sometimes obstruct the availability of menu items and guests sometimes have to cope with whatever is available. Chow Chow, local noodle is very famous in these all destination as it is instant and easily available in all the routes. It is also seen in some of the areas that tourists are participating in cooking with the hotel owners and cook for their choices and the cooks of these lodgeslearn the new dishes with them. All the lodges and eateries are good in preparing Nepalese food and are famous among the Nepalese tourists. Dal, Bhaat, Achar, Masu ( Curry, Rice, Chutney, and meat) cooked in Nepalese style are most popular items available anytime during lunch and dinner in any of the eateries however, being the spicy nature of the Nepalese cuisine, it is difficult to the Foreigners specially Europeans and Americans. Indians are used to with Nepalese food as being similar to their native food. Some tourists 
from west world are open to Nepalese food and like to take without hesitations and locals are also aware to make it less spicy for them.

The tourists flow is generally higher in August- November. Therefore there aren't too many options for staying at Kagbeni- Lo-manthang area (i.e. in upper mustang). The lodges are generally clean with common bathrooms and toilets. Hot water facility is available only to foreign tourists. Domestic tourists can avail the hot water facility by paying certain amount.

It is noticed that the locally made traditional tourist lodges are made in a transmodern way with a reflection of Nepalese traditional hospitality and the modern components of lodging facilities. Walls of the rooms are coated with locally available elastic kind of mud and are painted again with white and red mud found locally. Some of the lodges put adhesives in the mixture of colored mud fix it so that it does not come in contact with the body and clothes. Most of the lodges are not painted with the use of adhesives causing the paint coming out while being in touch with the body and other substances. Traditionally made lodges are shed with black thin stone and some are with the white and colored corrugated aluminum sheets. Mosquito nets are readily available for summer and most interesting is the local air conditioning system which is a wood fire chamber, locally known as chimney spreads from the restaurant to all the rooms till the roof for ventilation. The heat from the hearth goes via a tunnel to all the rooms and is escaped to the roof; this on the way makes the room warm. Accommodations are also available with the open fire system to maintain the temperature.

Government has totally ignored the condition of road from Beni-Jomsom. If the roads can be maintained, the revenue can be significantly increased. There aren't any workshops for repairing bikes, or any other vehicles except at Jomsom. Trekking routes to Annapurna circuit, Everest region, Langtang valley, Manaslu Circuit, Helambu and Gosainkunda lakes are in good conditions for trekking and after the recent earthquake of April 2015; there is a little disruption in roads and trails. Narrow trails are the only means of journey for both the porters and the tourists. They are so narrow and sometimes the porters can touch the upper part of the luggage in the cliffs and has the chances of accidents. The same trails are the trails for the herds of donkeys and ships which are the means of transportation for locals and it is difficult to pass on the way. Bushes and the slippery trails are much dangerous sometimes if not walked with cares.

No proper hospitals can be seen on the highway. Government can at least initiate the medical help facility during the peak tourist season. Health care facility is in poor condition in the high altitude areas in Nepal. Basic medical and other facilities are not ample in the trekking routes causing which, there is a singular risk associates with 
the traveller. If the traveller becomes sick, he/she has to walk for hours to reach to the hospital or health center.

Basic Hospitality norms are not widely practiced in these areas. Basic courtesy on receiving the guests, seating and farewell are not in proper standards. Things are done in a very traditional ways. Basic way of respect is to offer Namaste by joining two hands and offer thanks by saying Dhanyabad. Other basic etiquettes like body language, eye contacts, grooming standards, hygiene standards, mise-en-scene of the areas, etc. are not seemed to be well organized.

Hotel Everest view is situated within the Sagarmatha (Everest) National Park in Nepal which is a UNESCO world heritage site; this hotel offers a 360 degree view of the most awe inspiring peaks. Visitors observe and feel a mesmerizing scene of luxury while seeing the view of Mr. Everest from every room.

Opened in 1971, Hotel Everest view is listed don Guinness Book of world records in 2004 as being the highest placed hotel in the world at $1300 \mathrm{ft}$. This has been featured in many media and television and has become a destination in its own right. Hotel Everest view has become an example of the only hotel in the world providing luxury at the high altitude in the world for which Nepal is proud of. It is a perfect place from which the visitors explore the nearby villages and enjoy the eye-catching landscape filled with evergreen trees, shrubs and rhododendron forests. The dedicated staff provide with an excellent service and delicious cuisine to make the stay of the guests the most unforgettable experience. Hotel Everest view symbolizes the adventurous spirit of the Himalayas. It was way back 1969 when Takashi Miyahara first put his eyes on the magnificent Everest range from a ridge in Syangboche. His absolute breathtaking views captivated his heart and from that moment, he dared to dream that one day he would build a luxury hotel in the same location.

Even today, building a hotel at $3880 \mathrm{~m}$ height is next to impossible basically in Nepal because of its geography and accessibility. To have this hotel built in 60 's would have been a great challenge. Wight no accessibility, the construction of Hotel Everest view relied on the local porters carrying the construction materials on a two week trek from Lamusangu, which is $80 \mathrm{~km}$ from Kathmandu, the capital city of Nepal. Some of the items were transported from Helicopter. Blankets and eating utensils were all imported from japan. These were shipped to a port in Calcutta and then transported to Nepal.

This hotel was built with a dream that guests from all over the world can come and enjoy a 360 degree view of the Himalayas, appreciate Mt. Everest from every room and be treated with great hospitality. It is this unparalleled location and experience that makes a visit to Hotel Everest View a once in a lifetime trip. For a few, it is a journey that is taken many, many times. 
This shows that Nepal has a history of providing services and hospitality at very high altitudes.

\section{Recommendations and Suggestions}

Hospitality in High altitude starts from the Porters those who are deputized for the basic means of transportation of the food and belonging of the trekkers in these regions. The behavior of trekking guides is the most important elements of hospitality in these alpine routes. It is very fundamental to understand that the adventurous journey of nomad facilities by the locals should be encouraging, inspiring, motivating and supportive so that the traveller receives the maximum satisfaction of what he has opted for getting out of these alpine routes where there is always scarcity of a community which they belong to. Talking of hospitality in these routes, it is all a behavior and other actions which encourage the travelers to be more with the routes they are travelling. This behavior should be supported by good gestures, ready smile on face, good food, drinks and the accommodation, and rest is all manageable. The main goal of travelers should be to understand the psychology of the travelers and act accordingly to make their stay most memorable.

Emotional labor is potentially good. No customer wants to deal with a surly waitress, a crabby bank clerk, or a flight attendant who avoids eye contact in order to avoid getting a request. Lapses in courtesy by those paid to be courteous are very real and fairly common. What they show us is how fragile public civility really is. We are brought back to the question of what the social carpet actually consists of and what it requires of those who are supposed to keep it beautiful. The laggards and sluff-offs of emotional labor return us to the basic questions. What is emotional labor? What do we do when we manage emotion? What, in fact, is emotion? What are the costs and benefits of managing emotion, in private life and at work?(Hochschild, 2003)

${ }^{*}$ I use the term emotional labor to mean the management of feeling to create a publicly observable facial and bodily display; emotional labor is sold for a wage and therefore has exchange value. I use the synonymous terms emotion work or emotion management to refer to these same acts done in a private context where they have use value. (Hochschild, 2003)

Following are the important recommended attributes and body language and hospitality traits required for the service people in high altitudes

Smile on face

In the high altitudes, the trekkers are tired and are more often in a different state of mind. Sometimes are in a very good state of mind and sometimes are more anxious and a kind of down faced. It is very important to have a smile on face of the people deputized for hospitality in these routes. Smile on face signifies many positive 
impacts in the mind of the trekkers. This shows generosity, humbleness and a happy mood of service provider. A smile should be gentle and genuine which should reflect the state of our serving heart and attitude

\section{Patience and persistence}

Patience and persistence in the high altitude are key to a happy and fruitful experience for the travellers. The service holders should be of very high degree of patience and persistence while being in these infrequent and scares routes. The routes are sometimes difficult to elevate, food is not readily available and travel sometimes can become tiring and monotonous. In these circumstances the service providers should have lots of patience and persistence.

\section{Proactiveness and understanding}

It is important that the service providers should understand the needs and the wants of the travelers in advance; this is known as a proactive behavior. Since high altitude travelling is an adventurous experience, a proactive approach pleases the travelers and motivates them to enjoy their trip the fullest.

\section{Body language}

Attitude is displayed through the use of body language. The management and hospitable display of the service providers' body language has positive impacts on the customer experience. The position, movement of hands, eye contact, the originality of the smile, actions and words are very important.

Grooming and hygiene

Grooming and maintenance of one's personal hygiene as well as the workplace hygiene is another important aspect of the travel. The people involved in providing hospitality should maintain a high degree of grooming and hygiene standards. It is evident that the Alps are too cold and bathing everyday would not be possible as how it is possible in Terai region but the service providers should not be compromising the quality of services in connection with sanitation and hygiene. Short hair, close shaving, well-trimmed nails, management and tie up of the long hair of the ladies, uniform, bags and shoes should all be maintained in global hospitality standards.

(Karagianni, 2015, p. 184) stated, "Moreover attention is paid to the employee's overall appearance which should reflect a professional image and a positive attitude towards the visitor-client together with feelings of support and cooperation. Every employee, before he starts his work, should make a final check to his appearance, keeping always in mind that the first impression is very important to his contact with the visitor-client. Organizations and enterprises always require that employees should combine their personal traits and qualifications in the most constructive manner". 


\section{Graciousness and friendship}

It is important to offer hospitality with graciousness and show a friendly behavior to the travelers so that they make their trip a most remembering and have a feeling of being respected. Travelers in high Alps are with a mindset of achieving some adventurous experience and friendliness and humbleness from the service providers add value in their experiences

\section{Food and Beverage Services}

It is obvious that the Alps may or may not be avail of the high level of sophisticated service conditions, accommodation, staff and the equipment. A good management of services is required. The most important parameter of good service could be efficiency and effectiveness. Whatever food is served, whatever the bed provided, whatever are the facilities provided, it is important to do these all the things with lots of care with heart.

\section{Greetings and other basic etiquettes}

Basic etiquettes are very important. Etiquettes are directly connected with the body language. Formal greetings, wishing, paying respect, handshaking, smiling and showing empathy are the basic etiquettes of service people. It is necessary that the best service experience cannot be possible in absence of any of these qualities.

\section{Government concerns to improve basic hospitality in these routes}

Government of Nepal should have more concern about the basic infrastructure in trekking routes so as to give a comfortable journey experience to the travellers besides the elevations and muddy trails.

1. Trails can further be grouted or stoned to make them comfortable to walk. It is strongly recommended to have basic medical facilities for the travellers in all the trekking routes and standby helicopters for immediate rescue from different sites.

2. First aid training is important for locals and even the porters for an immediate service in emergencies.

3. Tourist police should be much utilized in trekking destinations for more secured journey for the travellers

4. Research team is required and an action oriented research is recommended for quick results

5. Security system should be improved in the lodges as there are no security companies deputized in these hilly regions

6. Hygiene, sanitation and safety training programs are important for the staff members of the lodges 
7. Basic courtesy guidelines should be taught to all the hotels, homestays and lodges

\section{Conclusion:}

This has been a very difficult and time consuming research as there are very less publications based on high altitude hospitality as people always treated this as a part of general hospitality and it is seen that no special attention is given to this kind of study before. After the study it is found that the high altitude destinations are most challenging venues and special care is important for the travelers, be it is home homestay hospitality or hospitality in hotels and Lodges. As pointed in the introduction and overview of this article, most of the books and journals of hospitality and tourism, generally talk about the history, trends and components of hospitality as a newly emerging discipline but there are a few books could only make significant contribution on the prospects, challenges and opportunities of hospitality especially in high altitudes where the challenges are ample. It is also found that people basically travel to altitudes to crave the places of adventures specially trekking, hiking, mountaineering, rock climbing, snow skiing, etc. Providing hospitality in high altitudes is a challenging task where there is always a scarcity of man, material and management. We use the word management to show up its direct proportionality with the man as a primary element of providing Hospitality. We have been living in the modern age where people travel for pleasure and find the most amazing yet very exhilarating destinations to have a very vacationing experience. Nepal as being a world destination for altitude climbing has a history connoted with Mt. Everest, the highest peak of the world. This has also been observed as to how the emotional labor as mentioned by Hochschild in his book "The Managed Heart" explained about the human factors that are important in providing hospitality services. The importance of feelings and its belongings on the offered services to the client and guests has a direct bearing on the overall experience and this experience is much important in high altitudes where the sentimental values are more important than the physical elements of a good service.

\section{References}

Bell, D. (2009). Tourism and Hospitality. In Jamal, T. \& Robinson, M. (Eds.). The Sage Handbook of Tourism Studies (PP.19-34).London: SAGE.

Cynthia M. Beall. (2011). Science Diplomacy in High-altitude: Tibetan Biology. Road Cleveland, Ohio: Case Western Reserve University.

Enz.Harisson, J.S., and Enz, C.A. (2005). Hospitality Strategic Management: Concept and Cases. Hoboken. New Jersey: John Wiley and Sons.

Hoschschild, A.R.(2003). The Managed Heart: Commercialization of Human feelings. London: University of California Press. 
Katagianni, M. (2015). Aesthetic Labour. International Journal of Humanities and Social Science, 5,182 -186.

Kendall, P. (2013). High Altitude Food Preparation. Retrieved from: http://extension. colostate.edu/topic-areas/nutrition-food-safety-health/high-altitude-foodpreparation-p41/

Khare, R.S.(1993). Indian Hospitality, Aspects of Cultural Models, Meaning and Use. In Bhat, C., Kachekar, L.N. \& Rao, N.R. (Eds.) Sociology of Development and Change (PP. 229-256) New Delhi: Orient Longman.

Kripaluji Maharaj, J. (1955). Prem Ras Siddhantha. Golok Dham. New Delhi: Radha: Govinda Samiti.

Kunwar, R.R.(2017). What is Hospitality? The Gaze: Journal of Tourism and Hospitality, $8(1), 55-115$.

Kunwar, R.R.(2017). Tourists and Tourism Revised and Enlarged Edition. Kathmandu: Ganga Sen Kunwar.

Lashley, C. (2000). Towards a Theoretical Understanding. In Lashley, C. \& Morrison, A. (Eds.) In Search of Hospitality: Theoretical Perspectives and Debates (pp. 1-17) London: Butterworth/Heinemann.

Lowden, P. (1998). Food, Ritual and Society: A Study of Social Structure and Food Symbolism among the Newars. Kathmandu: Mandala Book Point.

Ministry of Tourism and Civil Aviation Nepal. (2014). Nepal Tourism Statistics 2014,Kathmandu, Nepal:Ministry of Tourism and Civil Aviation.

Nutritional Advice for MilitaryOperationsina High-Altitude Environment(NAMOHAE), (2015). Retrieved from: http://www.acronymfinder.com/Nutritional-Advice-forMilitary-Operations-in-a-High_Altitude-Environment-(NAMOHAE).html

Swarbooke, J. \& Horner, S. (2007). Consumer Behavior in Tourism. Butterworth: Oxford.

The Economic Importance of Hospitality Industry Tourism Essay. Retrieved from: https://www.ukessays.com/essays/tourism/the-economic-importance-ofhospitality-industry-tourism-essay.php/

Upadhaya P. \& Uprety B. (2015). Mountain tourism in Nepal: An overview on the sustainable inclusion of local communities. Kathmandu, Nepal: Kathmandu University.

What is Hospitality Industry-Historical Background of Hospitality Industry. Retrieved from: https://soegjobs.com/2016/09/15/hospitality-industryhistorical-background/ 